\title{
Identifikasi status gizi, somatotipe, asupan makan dan cairan pada atlet atletik remaja di Indonesia
}

\author{
Mirza Hapsari Sakti Titis Penggalih, ${ }^{1, *}$ Mustika Cahya Nirmala Dewinta, ${ }^{2}$ Kurnia Mar'atus Solichah, ${ }^{2}$ \\ Diana Pratiwi, ${ }^{2}$ Ibtidau Niamilah, ${ }^{2}$ Almira Nadia, ${ }^{2}$ Marina Dyah Kusumawati ${ }^{3}$ \\ ${ }^{1}$ Departemen Gizi Kesehatan, Fakultas Kedokteran, Kesehatan Masyarakat, dan Keperawatan, \\ Universitas Gadjah Mada, Yogyakarta, Indonesia \\ ${ }^{2}$ First Sports Nutrition Consulting, Yogyakarta, Indonesia \\ ${ }^{3}$ Kementerian Pemuda dan Keolahragaan Republik Indonesia, Jakarta, Indonesia
}

\section{Submitted: 29 Agustus 2018 Revised: 10 Desember 2018 Accepted: 11 Desember 2018}

\begin{abstract}
ABSTRAK Status gizi, somatotipe, serta diet yang adekuat memiliki pengaruh terhadap performa atlet. Kajian terhadap aspek tersebut pada atlet remaja menjadi penting untuk membangun kondisi fisik atlet yang ideal sejak dini. Studi ini bertujuan untuk mengidentifikasi status gizi, somatotipe, serta asupan makan dan cairan atlet atletik remaja di Indonesia. Kajian dilakukan pada 25 atlet atletik remaja di Indonesia yang berasal dari Program Pembinaan dan Pelatihan Pelajar (PPLP) Daerah Istimewa Yogyakarta (DIY), PPLP Aceh, dan Sekolah Keolahragaan (SKO) Ragunan, Jakarta Selatan. Penentuan status gizi berdasarkan IMT/U dan TB/U. Kajian asupan makanan dan cairan dilakukan dengan wawancara 24-hour dietary recall dan kuesioner semi quantitative fluid frequency. Seluruh data dianalisa secara deskriptif serta ditampilkan dalam bentuk rata-rata dan nilai standar deviasi (SD). Nilai IMT/U pada seluruh atlet laki-laki berada pada rentang $-2 \mathrm{SD} \leq \mathrm{Z} \leq+1 \mathrm{SD}$ (normal) sedangkan sebagian atlet perempuan $+1 \mathrm{SD}<\mathrm{Z} \leq+2 \mathrm{SD}$ (gemuk). Nilai TB/U seluruh subjek dalam kategori normal (-2 SD $\leq Z \leq+2$ SD). Persen lemak subjek berkisar antara $12-16 \%$ pada atlet laki-laki dan 18-28\% pada atlet perempuan. Kategori somatotipe atlet laki-laki adalah ectomorphic mesomorph $(2,3-5,0-3,3)$ sedangkan atlet perempuan endomorphic mesomorph $(4,4-5,6-2,0)$. Pemenuhan energi dan karbohidrat $<80 \%$, sedangkan lemak $>110 \%$. Total asupan cairan per hari berkisar pada $2.700 \mathrm{ml}$ hingga $5.800 \mathrm{ml}$. Status gizi gemuk masih ditemukan pada atlet perempuan. Somatotipe yang sesuai dengan standar hanya ditemukan pada atlet laki-laki. Persen lemak berlebih dibandingkan nilai rekomendasi ditemukan pada kelompok atlet laki-laki maupun perempuan. Pemenuhan kebutuhan energi, zat gizi makro, zat gizi mikro, serta asupan cairan atlet secara keseluruhan masih tergolong kurang.
\end{abstract}

KATA KUNCI status gizi; somatotipe; asupan; atletik

ABSTRACT Athletes' nutrition status, somatotype, and adequate dietary intake are strongly related to their sport performance. Examining those markers in adolescent age is essential in order to develop the optimum physical characteristics for the future. This study was conducted to identify the nutrition status based on anthropometry value, somatotype, food and fluid intake of youth athletic athletes in Indonesia. Descriptive quantitative design was used in this study. Subjects participated in the study were 25 youth athletic athletes from Students Education and Training Program (Program Pembinaan dan Pelatihan Pelajar) in Yogyakarta and Aceh, and School of Sports (Sekolah Keolahragaan) Ragunan, Jakarta Selatan. Anthropometry measurement consists of body weight, height, body fat percentage, and somatotype. Nutrition status was identified according to BMI/age and height/age. Food and fluid intake were assessed using 24-hour dietary recall interview and semi quantitative fluid frequency questionnaire. Descriptive statistical analysis was performed and the result was presented in mean and standard deviation (SD). BMI/

\footnotetext{
*Corresponding author: Mirza H.S.T. Penggalih

Departemen Gizi Kesehatan, Fakultas Kedokteran, Kesehatan Masyarakat, dan Keperawatan, Universitas Gadjah Mada, Jl. Farmako, Sekip Utara, Yogyakarta 55281, Indonesia

Email: mirza.hapsari@ugm.ac.id / mirza_hapsari@yahoo.com
} 
age values in male and female athletes were $-2 S D \leq Z \leq+1 S D$ (normal) and $+1 S D<Z \leq+2 S D$ (overweight), respectively. Height/age value for both gender was normal in $-2 S D \leq Z \leq+2 S D$. Percentage of body fat ranged in $12-16 \%$ for males and $18-28 \%$ for females. Somatotype category for males was ectomorphic mesomorph (2.3-5.0-3.3) and endomorphic mesomorph (4.4-5.6-2.0) for females. Fulfillment of energy and carbohydrate was found inadequate ( $<80 \%)$, whereas fat intake was found excess ( $>110 \%)$. Total fluid intake was ranged from $2700 \mathrm{ml}$ to $5800 \mathrm{ml}$ per day. Overweight nutrition status was still found in female athletes. Ideal somatotype was found only in male athletes. Excessive percentage of body fat was detected in both gender. Total energy, macro nutrients, micro nutrients, and fluid intake were inadequate compared to dietary recommendation.

KEYWORDS nutrition status; somatotype; dietary intake; athletic

\section{Pendahuluan}

Pengukuran aspek status gizi, somatotipe, serta asupan makanan dan cairan pada atlet remaja merupakan hal yang penting untuk menilai kondisi fisik atlet. Hasil studi terdahulu mengungkapkan bahwa performa atlet tidak hanya dipengaruhi oleh keterampilan atlet, tetapi juga oleh kondisi fisiologis atlet dan pembinaan atlet. Kondisi fisiologis yang berpengaruh terhadap performa atlet antara lain denyut jantung, tekanan darah, somatotipe, status hidrasi, dan status gizi. ${ }^{1,2}$ Pengukuran status gizi dan somatotipe pada usia remaja sangat penting karena pembentukan tubuh akan lebih memungkinkan dilakukan ketika atlet masih dalam usia pertumbuhan. Kajian terhadap asupan makan dan cairan atlet penting dilakukan karena asupan zat gizi makro dan mikro berhubungan secara bermakna terhadap karakteristik antropometri dan perawakan tubuh atlet. ${ }^{3}$

Setiap atlet diharapkan memiliki karakteristik tubuh yang sesuai dengan cabang olahraga yang ditekuni, sehingga setiap atlet dengan cabang olahraga yang berbeda tidak dapat dibandingkan karakteristik tubuhnya. Perbedaan karakteristik tubuh pada seorang atlet menggambarkan karakteristik genetik dan jenis latihan yang rutin dilakukan. ${ }^{4}$ Beberapa cara dapat digunakan untuk mengetahui karakteristik tubuh pada atlet antara lain menggunakan pengukuran komposisi tubuh dan somatotipe.

Cabang olahraga atletik merupakan salah satu cabang olahraga tertua di dunia yang terdiri dari berbagai nomor perlombaan di antaranya lari, lempar, lompat, dan jalan cepat. Di Indonesia, atletik merupakan salah satu cabang olahraga yang banyak mendulang medali di berbagai kompetisi internasional. Pembinaan atlet atletik muda Indonesia sejak dini mulai dari pemantauan status gizi, komposisi tubuh, hingga penanaman pola diet seimbang sesuai kebutuhan adalah investasi jangka panjang untuk menunjang prestasi atlet. Studi ini bertujuan untuk mengkaji apakah atlet atletik remaja di Indonesia telah memiliki status gizi, somatotipe, dan pemenuhan kebutuhan gizi yang baik sesuai dengan standar atlet atletik profesional.

\section{Metode}

Kajian ini merupakan studi non-eksperimental yang dilakukan menggunakan metode deskriptif dengan pendekatan kuantitatif. Pengolahan, analisis, dan penyajian data yang diperoleh dari pengukuran kuantitatif dilakukan secara deskriptif.

Sebanyak 25 atlet atletik remaja Indonesia berpartisipasi dalam kajian ini, terdiri dari 15 atlet laki-laki dan 10 atlet perempuan, dengan rentang usia 13-17 tahun dan usia rata-rata 14,8 tahun. Subjek merupakan atlet atletik remaja Indonesia yang tergabung dalam Program Pembinaan dan Pelatihan Pelajar (PPLP) Daerah Istimewa Yogyakarta (DIY), PPLP Aceh, dan atlet atletik dari Sekolah Keolahragaan (SKO) Ragunan, Jakarta Selatan.

Pengambilan data dilakukan selama tiga periode, yaitu 10-14 Juni 2015 di Asrama Atlet 
Ragunan, Kementerian Pemuda dan Olahraga (Kemenpora) Republik Indonesia, Jakarta Selatan, 7 Oktober 2017 di Gelanggang Pemuda Sorowajan, Yogyakarta, dan 11-14 November 2017 di Stadion Harapan Bangsa, Banda Aceh.

\subsection{Pengukuran status gizi}

Aspek antropometri yang diukur adalah tinggi badan dan berat badan. Pengukuran tinggi badan dilakukan dengan menggunakan $\mathrm{GEA}^{\circledR}$ stature meter. Karada Scan Bioelectrical Impedance Analysis (BIA) digunakan untuk mengukur berat badan dan persen lemak tubuh. Data tinggi badan dan berat badan digunakan untuk menghitung nilai indeks massa tubuh (IMT). IMT menurut umur (IMT/U) dan tinggi badan menurut umur (TB/U) digunakan sebagai indikator penilaian status gizi atlet karena atlet yang terlibat berusia di bawah 19 tahun. Indikator IMT/U dan TB/U dihitung dengan melibatkan komponen berat badan dan tinggi badan, dinyatakan berdasarkan nilai Z-score menggunakan aplikasi WHO Anthro Plus. Kategori status gizi berdasarkan IMT/U ditampilkan dalam Tabel 1.

\subsection{Pengukuran somatotipe}

Pengukuran somatotipe dilakukan menggunakan skinfold caliper, spreading caliper, dan pita ukur Metline ${ }^{\circledast}$ dengan mengukur 11 komponen tubuh yaitu tinggi badan, berat badan, lipatan kulit trisep, lipatan kulit subskapula, lipatan kulit suprailliaka, lipatan kulit betis, lebar tulang biepicondilar humerus, lebar tulang biepicondilar femur, lingkar lengan tegang (LLT), dan lingkar betis. Nilai somatotipe diperoleh dari perhitungan seluruh komponen yang telah diukur menggunakan formula The Heath-Carter $2005 .{ }^{6}$

\subsection{Penilaian asupan makan dan cairan}

Penentuan status gizi berdasarkan asupan makanan dan minuman menggunakan metode wawancara 24-hour dietary recall pada satu hari terakhir dan semi quantitative fluid frequency questionnaire (SQ-FFQ) selama satu minggu
Tabel 1. Status gizi berdasarkan IMT/U dan TB/ $\mathrm{U}^{5}$

\begin{tabular}{lc}
\hline Status gizi (IMT/U) & Z-Score \\
\hline Sangat kurus & $Z<-3 \mathrm{SD}$ \\
Kurus & $-3 \mathrm{SD} \leq \mathrm{Z}<-2 \mathrm{SD}$ \\
Normal & $-2 \mathrm{SD} \leq \mathrm{Z} \leq+1 \mathrm{SD}$ \\
Gemuk & $+1 \mathrm{SD}<\mathrm{Z} \leq+2 \mathrm{SD}$ \\
Obesitas & $\mathrm{Z}>+2 \mathrm{SD}$ \\
\hline Status Gizi (TB/U) & $Z$-Score \\
\hline Sangat pendek & $\mathrm{Z}<-3 \mathrm{SD}$ \\
Pendek & $-3 \mathrm{SD} \leq \mathrm{Z}<-2 \mathrm{SD}$ \\
Normal & $-2 \mathrm{SD} \leq \mathrm{Z} \leq+2 \mathrm{SD}$ \\
Tinggi & $\mathrm{Z}>2 \mathrm{SD}$ \\
\hline
\end{tabular}

SD: standar deviasi; IMT: indeks massa tubuh; U: umur.

terakhir. Hasil perhitungan asupan zat gizi dibandingkan dengan kebutuhan masing-masing atlet. Kebutuhan gizi pada atlet diketahui dengan melakukan perhitungan energi aktivitas dan energi untuk latihan. Perhitungan energi kegiatan sehari-hari (energi aktivitas) dilakukan dengan mengalikan energi basal dengan faktor aktivitas yang sesuai. Energi basal diperoleh dari formulasi Karada Scan BIA dengan penyesuaian usia dan jenis kelamin. Tambahan energi usia pertumbuhan juga dimasukkan dalam perhitungan aktivitas seharihari. Sedangkan, energi latihan dihitung sesuai dengan jenis cabang olahraga, durasi latihan, dan berat badan masing-masing atlet.

Asupan dibandingkan kebutuhan kemudian diinterpretasikan pemenuhannya berdasarkan kategori kurang, baik, atau lebih. Pemenuhan asupan dinyatakan kurang apabila asupan atlet berada di bawah nilai $80 \%$. Apabila asupan atlet berada pada rentang $80-110 \%$ dari kebutuhannya maka asupan dinyatakan baik. Pemenuhan asupan dinyatakan lebih apabila persentasenya melebihi dari kebutuhan yang telah ditetapkan.

Analisis statistik deskriptif dilakukan untuk mengetahui nilai rata-rata setiap variabel pengukuran. Analisis dilakukan menggunakan perangkat lunak SPSS versi 16 . Hasil analisis data dipaparkan dalam bentuk rata-rata dengan standar deviasi (SD). Kajian ini dilakukan di bawah pengawasan Pusat Pengembangan IPTEK dan Olahraga Nasional (PPITKON) Kemenpora 
Republik Indonesia dengan nomer referensi 092.01.06.3827.006.001.052.

\section{Hasil}

\subsection{Karakteristik subjek}

Subjek adalah atlet atletik binaan PPITKON Kemenpora RI yang menjalani pelatihan di bawah PPLP DIY, PPLP Aceh, dan SKO Ragunan, Jakarta Selatan. Subjek yang berpartisipasi sebanyak 25 orang terdiri dari 15 atlet laki-laki dan 10 atlet perempuan dengan rentang usia 13-17 tahun. Kategori atletik yang digeluti adalah lari $(n=13)$, lompat $(n=5)$, lempar $(n=6)$, dan jalan cepat $(n=1)$. Atlet yang terlibat merupakan atlet profesional yang memiliki jadwal pertandingan dua hingga empat kali setiap tahun baik di tingkat provinsi, nasional, maupun internasional.

\subsection{Penilaian status gizi}

Aspek antropometri yang diukur adalah berat badan dan tinggi badan untuk memperoleh data IMT, IMT/U, dan TB/U. Data pengukuran antropometri ditampilkan pada Tabel 2. Hasil pengukuran menunjukkan bahwa nilai IMT atlet atletik laki-laki di ketiga kelompok memiliki rentang 20-21, Z-score TB/U -0,04 SD hingga -0,9 SD, Z-score IMT/U 0 SD hingga -0,2 SD, dan persentase lemak tubuh 1216\%. Berdasarkan nilai IMT/U dan TB/U tersebut diketahui bahwa atlet atletik laki-laki dalam kajian ini memiliki status gizi normal dengan nilai Z-score IMT/U di antara -2 SD dan +1 SD dan Z-score TB/U di antara -2 SD dan +2 SD.
Nilai IMT atlet atletik perempuan berada pada rentang 17-26, Z-score TB/U 0 SD hingga -0,9 SD, $Z$-score IMT/U -1 SD hingga +1,4 SD, dan persentase lemak tubuh $18-28 \%$. Status gizi berdasarkan IMT/U atlet atletik perempuan yang berada pada rentang $+1 \mathrm{SD}<\mathrm{Z} \leq+2 \mathrm{SD}$ dikategorikan sebagai gemuk atau overweight, yang ditemukan pada kelompok atlet PPLP Aceh dan SKO Ragunan.

Referensi persentase lemak tubuh atlet profesional laki-laki dan perempuan pada olahraga atletik masing-masing adalah $7,3 \%$ dan $12,8 \%$, sehingga pada kajian ini persen lemak yang dimiliki atlet laki-laki maupun perempuan lebih tinggi dibandingkan nilai referensi.

\subsection{Somatotipe atlet}

Datasomatotipe diperoleh berdasarkan pengukuran komponen antropomoteri yang meliputi berat badan, tinggi badan, lipatan kulit, lebar tulang, dan lingkar tubuh. Hasil pengukuran komponen lipatan kulit (Tabel 3) menunjukkan bahwa rata-rata lipatan kulit pada atlet atletik laki-laki lebih rendah daripada atlet atletik perempuan, sedangkan hasil pengukuran lebar tulang dan lingkar tubuh (Tabel 4) menunjukkan nilai yang bervariasi pada atlet laki-laki maupun perempuan.

Formulasi hasil pengukuran TB, BB, tebal lipatan kulit, lebar tulang, dan lingkar tubuh membentuk tiga komponen somatotipe, yaitu endomorf, mesomorf, dan ektomorf. ${ }^{8}$ Data somatotipe pada Tabel 5 menunjukkan bahwa ratarata nilai endomorf, mesomorf, dan ektomorf atlet

Tabel 2. Hasil pengukuran antropometri pada atlet atletik dari PPLP DIY, PPLP Aceh, dan SKO Ragunan

\begin{tabular}{llcccccc}
\hline Jenis Kelamin & Kelompok & BB $\mathbf{( k g})$ & TB $(\mathbf{c m})$ & IMT & TB/U & IMT/U & \%Lemak \\
\hline Laki-laki & PPLP DIY & $58,7 \pm 11,9$ & $166,6 \pm 8,3$ & $20,9 \pm 3,5$ & $-0.9 \pm 0,8$ & $-0,2 \pm 1,1$ & $16,1 \pm 3,5$ \\
& PPLP Aceh & $62,1 \pm 10,6$ & $173,4 \pm 3,8$ & $20,7 \pm 3,3$ & $-0,04 \pm 0,35$ & $-0,23 \pm 1,2$ & $12,8 \pm 5,1$ \\
& SKO Ragunan & $60,9 \pm 8,4$ & $169,2 \pm 10,4$ & $21,3 \pm 2,1$ & $-0,7 \pm 1,2$ & $0,0 \pm 0.8$ & $12,4 \pm 2,8$ \\
\multirow{4}{*}{ Perempuan } & PPLP DIY & $38,3 \pm 15,3$ & $147,6 \pm 11,8$ & $17,2 \pm 4,2$ & $-0,9 \pm 0,1$ & $-1,0 \pm 1,0$ & $18,0 \pm 4,2$ \\
& PPLP Aceh & $66,6 \pm 26,4$ & $159,8 \pm 10,1$ & $25,6 \pm 7,3$ & $-0,2 \pm 1,2$ & $1,3 \pm 1,4$ & $28,3 \pm 5,7$ \\
& SKO Ragunan & $68,0 \pm 14,9$ & $161,4 \pm 8,0$ & $25,9 \pm 4,0$ & $0,0 \pm 0,9$ & $1,4 \pm 0,9$ & $28,2 \pm 4,5$ \\
\hline
\end{tabular}

PPLP: Program Pembinaan dan Pelatihan Pelajar; SKO: Sekolah Keolahragaan; DIY: Daerah Istimewa Yogyakarta; BB: berat badan; TB: tinggi badan; IMT: indeks massa tubuh; U: umur. 
laki-laki adalah 2,3-5,3-3,3 yang termasuk dalam kategori ectomorphic mesomorph. Rata-rata nilai somatotipe pada atlet perempuan adalah 4,4-5,62,0 yang termasuk dalam kategori endomorphic mesomorph.

\subsection{Penilaian asupan makan dan cairan}

Penggalian data asupan makan dilakukan dengan metode wawancara 24-hour dietary recall, sementara data asupan cairan diperoleh dari kuesioner SQ-FFQ. Besarnya kebutuhan, asupan,

Tabel 3. Hasil pengukuran lipatan kulit pada atlet atletik dari PPLP DIY, PPLP Aceh, dan SKO Ragunan

\begin{tabular}{llcccc}
\hline Jenis Kelamin & Kelompok & Trisep $(\mathrm{mm})$ & Subskapula $(\mathrm{mm})$ & Suprailiaka $(\mathrm{mm})$ & Betis $(\mathrm{mm})$ \\
\hline Laki-laki & PPLP DIY & $6,1 \pm 3,0$ & $8,6 \pm 3,1$ & $7,4 \pm 3,3$ & $5,1 \pm 2,4$ \\
& PPLP Aceh & $7,9 \pm 5,1$ & $9,7 \pm 2,8$ & $8,1 \pm 4,4$ & $8,5 \pm 1,7$ \\
& SKO Ragunan & $6,8 \pm 1,8$ & $9,2 \pm 2,8$ & $7,6 \pm 2,3$ & $7,6 \pm 2,3$ \\
\multirow{3}{*}{ Perempuan } & PPLP DIY & $9,4 \pm 7,6$ & $6,7 \pm 3,2$ & $5,8 \pm 2,1$ & $6,5 \pm 3,1$ \\
& PPLP Aceh & $23,6 \pm 10,4$ & $11 \pm 1,4$ & $21,2 \pm 15,2$ & $30,5 \pm 7,3$ \\
& SKO Ragunan & $17,1 \pm 9,0$ & $16,3 \pm 6,6$ & $19,6 \pm 11,6$ & $15,0 \pm 5,4$ \\
\hline
\end{tabular}

PPLP: Program Pembinaan dan Pelatihan Pelajar; SKO: Sekolah Keolahragaan; DIY: Daerah Istimewa Yogyakarta.

Tabel 4. Hasil pengukuran lebar tulang, lingkar lengan tegang, dan lingkar betis pada atlet atletik dari PPLP DIY, PPLP Aceh, dan SKO Ragunan

\begin{tabular}{llcccc}
\hline Jenis Kelamin & \multicolumn{1}{c}{ Kelompok } & $\begin{array}{c}\text { Lebar humerus } \\
(\mathbf{c m})\end{array}$ & $\begin{array}{c}\text { Lebar femur } \\
(\mathbf{c m})\end{array}$ & $\begin{array}{c}\text { LLT } \\
(\mathbf{c m})\end{array}$ & $\begin{array}{c}\text { Lingkar betis } \\
(\mathbf{c m})\end{array}$ \\
\hline Laki-laki & PPLP DIY & $6,7 \pm 0,7$ & $9,5 \pm 0,6$ & $27,5 \pm 4,5$ & $34,8 \pm 3,7$ \\
& PPLP Aceh & $6,8 \pm 0,5$ & $9,2 \pm 0,3$ & $30,0 \pm 5,6$ & $31,4 \pm 2,7$ \\
& SKO Ragunan & $9,0 \pm 0,1$ & $11,5 \pm 0,5$ & $28,0 \pm 5,8$ & $35,7 \pm 1,5$ \\
Perempuan & PPLP DIY & $5,7 \pm 0,3$ & $7,7 \pm 1,1$ & $19,9 \pm 4,1$ & $30,8 \pm 6,1$ \\
& PPLP Aceh & $6,0 \pm 0,0$ & $8,7 \pm 0,3$ & $30,5 \pm 7,3$ & $37,8 \pm 5,9$ \\
& SKO Ragunan & $8,2 \pm 0,4$ & $11,7 \pm 0,5$ & $30,8 \pm 4,0$ & $38,1 \pm 3,1$ \\
\hline
\end{tabular}

PPLP: Program Pembinaan dan Pelatihan Pelajar; SKO: Sekolah Keolahragaan; DIY: Daerah Istimewa Yogyakarta; LLT: lingkar lengan tegang.

Tabel 5. Hasil perhitungan komponen somatotipe atlet atletik dari PPLP DIY, PPLP Aceh, dan SKO Ragunan

\begin{tabular}{llccc}
\hline Jenis Kelamin & \multicolumn{1}{c}{ Kelompok } & Endomorf & Mesomorf & Ectomorf \\
\hline Laki-laki & PPLP DIY & 2,1 & 4,8 & 3,0 \\
& PPLP Aceh & 2,5 & 3,4 & 4,0 \\
& SKO Ragunan & 2,3 & 7,7 & 3,0 \\
& Rata-rata & 2,3 & 5,3 & 3,3 \\
\multirow{5}{*}{ Perempuan } & 2,4 & 3,1 & 3,9 \\
& PPLP DIY & 5,6 & 4,8 & 1,1 \\
& PPLP Aceh & 5,2 & 8,8 & 1,0 \\
& SKO Ragunan & 4,4 & 5,6 & 2,0 \\
\hline
\end{tabular}

PPLP: Program Pembinaan dan Pelatihan Pelajar; SKO: Sekolah Keolahragaan; DIY: Daerah Istimewa Yogyakarta. 
Tabel 6. Kebutuhan, asupan, dan pemenuhan energi dan zat gizi makro pada atlet atletik dari PPLP DIY, PPLP Aceh, dan SKO Ragunan

\begin{tabular}{|c|c|c|c|c|}
\hline Kelompok & Komponen & Endomorf & Mesomorf & Ectomorf \\
\hline & Energi & & & \\
\hline & Basal, kkal & $1.249 \pm 222$ & & \\
\hline & Aktivitas, kkal & $1.850 \pm 366$ & & \\
\hline & Latihan, kkal & $797 \pm 298$ & & \\
\hline \multirow[t]{9}{*}{ PPLP DIY } & Total energi, kkal & $2.646 \pm 497$ & $1.970 \pm 540$ & $75 \pm 17$ \\
\hline & Zat gizi makro & & & \\
\hline & Protein, $\mathrm{g}$ & $99 \pm 19$ & $74 \pm 22$ & $81 \pm 19$ \\
\hline & Lemak, g & $59 \pm 11$ & $74 \pm 14$ & $126 \pm 16$ \\
\hline & Karbohidrat, g & $430 \pm 81$ & $281 \pm 92$ & $65 \pm 17$ \\
\hline & Energi & & & \\
\hline & Basal, kkal & $1.488 \pm 109$ & & \\
\hline & Aktivitas, kkal & $2.192 \pm 224$ & & \\
\hline & Latihan, kkal & $1.382 \pm 341$ & & \\
\hline \multirow[t]{9}{*}{ PPLP Aceh } & Total energi, kkal & $3.519 \pm 498$ & $2.227 \pm 226$ & $64 \pm 8$ \\
\hline & Zat gizi makro & & & \\
\hline & Protein, g & $134 \pm 19$ & $89 \pm 16$ & $68 \pm 16$ \\
\hline & Lemak, g & $78 \pm 11$ & $85 \pm 19$ & $112 \pm 29$ \\
\hline & Karbohidrat, g & $572 \pm 81$ & $290 \pm 46$ & $51 \pm 15$ \\
\hline & Energi & & & \\
\hline & Basal, kkal & $1.435 \pm 185$ & & \\
\hline & Aktivitas, kkal & $1.939 \pm 238$ & & \\
\hline & Latihan, kkal & $1.419 \pm 306$ & & \\
\hline \multirow[t]{5}{*}{ SKO Ragunan } & Total energi, kkal & $3.358 \pm 463$ & $2.334 \pm 815$ & $69 \pm 20$ \\
\hline & Zat gizi makro & & & \\
\hline & Protein, $\mathrm{g}$ & $126 \pm 17$ & $101 \pm 17$ & $80 \pm 26$ \\
\hline & Lemak, g & $75 \pm 10$ & $94 \pm 10$ & $124 \pm 45$ \\
\hline & Karbohidrat, g & $545 \pm 75$ & $278 \pm 75$ & $51 \pm 14$ \\
\hline
\end{tabular}

Data asupan dan pemenuhan asupan disajikan dalam rata-rata \pm SD. Perhitungan kebutuhan protein, lemak dan karbohidrat didasarkan pada 15\%; 20\%; 65\% dari kebutuhan energi total. PPLP: Program Pembinaan dan Pelatihan Pelajar; SKO: Sekolah Keolahragaan; DIY: Daerah Istimewa Yogyakarta.

serta pemenuhan energi dan zat gizi makro ditampilkan pada Tabel 6 .

Data asupan makan menunjukkan bahwa atlet di PPLP DIY, PPLP Aceh, maupun SKO Ragunan memiliki pemenuhan energi dan karbohidrat yang kurang $(<80 \%)$, sedangkan asupan lemak ditemukan berlebih (>110\%) dibandingkan jumlah yang direkomendasikan. Pemenuhan protein yang masih kurang $(<80 \%)$ ditemukan pada kelompok atlet PPLP Aceh, sementara pemenuhan protein pada dua kelompok lain termasuk baik.

Data asupan zat gizi mikro yang diperoleh pada penelitian ini (Tabel 7) menunjukkan bahwa atlet masih memiliki rata-rata asupan inadekuat untuk beberapa zat gizi mikro yaitu zink, kalsium, fosfor, asam folat, serat, dan vitamin D. Asupan zat-zat gizi 
Tabel 7. Asupan dan kebutuhan zat gizi mikro atlet atletik dari PPLP DIY, PPLP Aceh, dan SKO Ragunan

\begin{tabular}{|c|c|c|c|c|c|c|c|c|c|c|c|c|}
\hline & $\begin{array}{c}\mathrm{Fe} \\
\text { (mg) }\end{array}$ & $\begin{array}{l}\mathrm{Zn} \\
(\mathrm{mg})\end{array}$ & $\begin{array}{c}\mathrm{Ca} \\
\text { (mg) }\end{array}$ & $\begin{array}{c}P \\
(\mathrm{mg})\end{array}$ & $\begin{array}{c}\mathrm{Mg} \\
\text { (mg) }\end{array}$ & $\begin{array}{l}\text { As, } \\
\text { Folat } \\
\text { (mcg) }\end{array}$ & $\begin{array}{l}\text { Kol } \\
\text { (mg) }\end{array}$ & $\begin{array}{c}\text { Serat } \\
\text { (g) }\end{array}$ & $\begin{array}{r}\text { Vit A } \\
\text { (mcg) }\end{array}$ & $\begin{array}{l}\text { Vit C } \\
\text { (mcg) }\end{array}$ & $\begin{array}{l}\text { Vit, D } \\
\text { (mcg) }\end{array}$ & $\begin{array}{l}\text { Vit, } \\
\text { B12 } \\
\text { (mg) }\end{array}$ \\
\hline \multicolumn{13}{|l|}{ Asupan } \\
\hline PPLP DIY & 11,4 & 3,7 & 387,6 & 716,9 & 83,8 & 95,8 & 244 & 6,4 & 839,4 & 33,8 & 0,9 & 3,2 \\
\hline PPLP Aceh & 15 & 7.8 & 402 & 970 & 143 & 175 & 223 & 6.8 & 323 & 35 & 3,8 & 2,2 \\
\hline SKO Ragunan & 20 & 12 & 821 & 956 & 303 & 203 & 187 & 12 & 1.123 & 106 & 2,5 & 1,5 \\
\hline Rata-rata & 17,5 & 9,9 & 611,5 & 963 & 223 & 189 & 218 & 9,4 & 723 & 70,5 & 2,4 & 2,3 \\
\hline \multicolumn{13}{|l|}{ Rekomendasi } \\
\hline AKG 2013* & $13-26$ & $13-18$ & 1.200 & 1.200 & $150-250$ & 400 & $<200$ & $28-37$ & 600 & $50-90$ & 15 & $1,8-2,4$ \\
\hline
\end{tabular}

*Angka Kecukupan Gizi (AKG). 2013. Tabel Angka Kecukupan Gizi Bagi Bangsa Indonesia. Peraturan Menteri Kesehatan Republik Indonesia Nomor 75 Tahun 2013. PPLP: Program Pembinaan dan Pelatihan Pelajar; SKO: Sekolah Keolahragaan; DIY: Daerah Istimewa Yogyakarta.

Tabel 8. Asupan cairan dari berbagai jenis minuman atlet atletik dari PPLP DIY, PPLP Aceh, dan SKO Ragunan

\begin{tabular}{lccc}
\hline \multirow{2}{*}{ Jenis Minuman } & \multicolumn{3}{c}{ Rata-rata Asupan/Hari (mL) } \\
\cline { 2 - 4 } & PPLP DIY & PPLP Aceh & SKO Ragunan \\
\hline Air mineral & $1.837 \pm 444$ & $3.117 \pm 807$ & $4.350 \pm 1.069$ \\
Susu, susu fermentasi, yoghurt, es krim & $270 \pm 232$ & $113 \pm 79$ & $396 \pm 213$ \\
Sari kedelai, kacang hijau, sari kacang-kacangan & $47 \pm 166$ & $33 \pm 11$ & $52 \pm 99$ \\
Minuman tak berkabonasi mengandung gula & $146 \pm 66$ & $124 \pm 97$ & $828 \pm 174$ \\
Minuman berkarbonasi mengandung gula & $13 \pm 38$ & $21 \pm 12$ & $6 \pm 16$ \\
Minuman berenergi & $0 \pm 0$ & $34 \pm 17$ & $0 \pm 0$ \\
Minuman isotonis & $66 \pm 76$ & $36 \pm 51$ & $89 \pm 109$ \\
Jus buah, minuman sari buah & $137 \pm 124$ & $232 \pm 328$ & $44 \pm 37$ \\
Minuman vitamin C & $47 \pm 37$ & $15 \pm 14$ & $20 \pm 22$ \\
Lain-lain (minuman berempah dan penyegar) & $25 \pm 71$ & $14 \pm 20$ & $13 \pm 26$ \\
Total & $2.691 \pm 850$ & $3.587 \pm 955$ & $5.796 \pm 860$ \\
\hline
\end{tabular}

PPLP: Program Pembinaan dan Pelatihan Pelajar; SKO: Sekolah Keolahragaan; DIY: Daerah Istimewa Yogyakarta.

mikro tersebut masih di bawah nilai rekomendasi berdasarkan Angka Kecukupan Gizi (AKG) Tahun 2013 untuk populasi usia 10-18 tahun. Asupan zat gizi mikro yang sudah memenuhi rekomendasi adalah asupan zat besi, magnesium, vitamin $\mathrm{C}$, dan vitamin $\mathrm{B}_{12}$. Asupan kolesterol dan vitamin A lebih besar daripada jumlah yang direkomendasikan (Tabel 7).

Berdasarkan hasil penggalian asupan cairan diketahui bahwa jenis minuman atlet atletik dalam studi ini sudah bervariasi, di mana proporsi asupan tertinggi adalah air mineral (Tabel 8). Selain air mineral, jenis minuman lain yang paling sering dikonsumsi adalah susu dan olahannya, jus buah dan sari buah, minuman tak berkarbonasi mengandung gula, serta minuman isotonis. Ratarata total asupan cairan per hari pada ketiga kelompok berada pada rentang $2.700 \mathrm{ml}$ hingga $5.800 \mathrm{ml}$. Asupan total cairan tertinggi dimiliki oleh kelompok atlet SKO Ragunan, diikuti oleh PPLP Aceh kemudian PPLP DIY. Asupan minuman berenergi hanya ditemukan pada atlet atletik PPLP Aceh. 


\section{Pembahasan}

Pengukuran antropometri bertujuan untuk mengidentifikasi status gizi, komposisi tubuh, dan kategori somatotipe atau perawakan tubuh atlet. Penilaian status gizi berdasarkan aspek antropometri dan komposisi tubuh menjadi pengukuran yang fundamental untuk mengevaluasi dan memonitor kondisi fisik atlet, yang berperan penting dalam pencapaian performa atlet. ${ }^{10} \mathrm{Di}$ samping itu, penilaian status gizi pada atlet remaja penting untuk memastikan atlet tumbuh dan berkembang secara optimal. Fase pertumbuhan dan perkembangan remaja yang dinamis dan cepat ditandai dengan perubahan ukuran tubuh, bentuk tubuh, dan komposisi tubuh yang berbeda antara laki-laki dan perempuan. Selama pubertas, diperkirakan remaja mencapai $50 \%$ dari berat badan dewasa, 20\% tinggi badan dewasa dan $45 \%$ otot rangka dewasa. ${ }^{11}$

Penilaian status gizi atlet atletik remaja dalam studi ini dilakukan berdasarkan indeks tinggi badan menurut umur (TB/U) dan indeks massa tubuh menurut umur (IMT/U). Indikator $\mathrm{TB} / \mathrm{U}$ memberikan petunjuk ada tidaknya masalah gizi yang bersifat kronis sebagai akibat keadaan yang berlangsung lama, sementara indikator IMT/U memberikan petunjuk ada tidaknya masalah gizi yang bersifat akut. ${ }^{12}$ Studi ini menemukan bahwa masih terdapat atlet atletik yang memiliki status gizi gemuk atau overweight pada atlet perempuan. Kondisi ini menjadi catatan agar atlet menurunkan berat badan hingga mencapai status gizi ideal. Atlet yang telah memiliki status gizi normal perlu dipertahankan supaya mencapai pertumbuhan dan perkembangan yang optimal hingga dewasa sehingga performanya di masa mendatang baik.

Persentase lemak tubuh merupakan salah satu komponen pengukuran antropometri yang sangat penting, karena setiap aspek performa seperti kekuatan, ketahanan, fleksibilitas, kecepatan, dan kelincahan memiliki hubungan erat dengan persentase lemak tubuh atlet. ${ }^{13}$ Perhatian terhadap kondisi fisik atlet atletik remaja dalam kajian ini juga perlu ditingkatkan mengingat hasil pengukuran persentase lemak tubuh atlet, yang berkisar pada nilai $12-16 \%$ untuk laki-laki dan $18-$ $28 \%$ untuk perempuan, lebih besar dibandingkan referensi persentase lemak tubuh atlet atletik semi-profesional yaitu 7,3\% untuk laki-laki dan $12,8 \%$ untuk perempuan. ${ }^{7}$ Penyimpanan lemak tubuh cenderung mengalami peningkatan di usia pubertas karena perubahan sistem hormonal terutama pada perempuan, sehingga penurunan persentase lemak tubuh sesuai nilai rekomendasi perlu ditingkatkan pada usia ini melalui intervensi diet dan peningkatkan latihan untuk meningkatkan massa otot. ${ }^{14}$

Perhatian terhadap persen lemak tubuh sangat penting karena persen lemak tubuh berlebih akan berpengaruh negatif terhadap performa olahraga. Hal tersebut terjadi karena sifatnya berlawanan dengan proses pembentukan kekuatan dan massa otot. ${ }^{15}$ Peningkatan lemak tubuh dapat berpengaruh pada menurunnya kecepatan dan kekuatan gerakan atlet. Hal tersebut berpengaruh pada atlet olahraga yang mengandalkan kecepatan dan kekuatan, termasuk cabang olahraga atletik. ${ }^{16}$

Pengukuran somatotipe atlet dilakukan untuk mengetahui apakah perawakan tubuh atlet yang dimiliki sesuai dengan perawakan tubuh yang ideal untuk cabang olahraga sejenis. Berdasarkan hasil pengukuran, diketahui bahwa somatotipe atlet atletik laki-laki dalam studi ini termasuk kategori ektomorfik mesomorf (2,3-5,3-3,3). Nilai tersebut sesuai dengan nilai referensi berdasarkan hasil kajian terhadap atlet atletik profesional bahwa nilai somatotipe ideal untuk atlet atletik adalah $(1,6-2,7-4,2)^{7}$ yang termasuk ke dalam kategori mesomorfik ektomorf. Kategori somatotipe pada atlet atletik perempuan pada studi ini adalah endomorfik mesomorf $(4,4-5,6-2,0)$, sementara kategori somatotipe pada atlet atletik perempuan profesional adalah mesomorfik ektomorf $(2,0-2,7-$ $4,0) .^{7}$

Komponen mesomorf yang optimal memiliki peran penting dalam performa pelari, karena komposisi otot yang tinggi akan memaksimalkan daya dan kekuatan tubuh. Komponen tubuh mesomorf tidak terbentuk secara alami, namun diperlukan latihan yang tepat dan konsisten. Latihan 
dalam jangka waktu yang lama tanpa disertai latihan kekuatan atau pembebanan otot yang tepat tidak dapat menghasilkan daya ledak yang baik pada atlet lari jarak dekat. ${ }^{8,12}$ Komponen mesomorf dan endomorf yang berlebihan pada atlet atletik sangat berpengaruh pada performa atlet yang bersangkutan. Oleh karena itu, diperlukan program terintegrasi dalam perencanaan makan dan latihan yang tepat untuk untuk memodifikasi morfologi tubuh sesuai dengan somatotipe spesifik cabang olahraga.

Data asupan makan menunjukkan bahwa atlet memiliki pemenuhan energi dan karbohidrat yang kurang $(<80 \%)$, sedangkan asupan lemak ditemukan berlebih (>110\%) dibandingkan jumlah yang direkomendasikan. Pemenuhan protein yang masih kurang $(<80 \%)$ ditemukan pada kelompok atlet PPLP Aceh, sementara pemenuhan protein pada dua kelompok lain termasuk baik. Data asupan zat gizi mikro menunjukkan bahwa atlet masih memiliki rata-rata asupan yang tidak cukup untuk beberapa zat gizi mikro yaitu zink, kalsium, fosfor, asam folat, serat, dan vitamin D. Asupan zat-zat gizi mikro tersebut masih di bawah nilai rekomendasi berdasarkan angka kecukupan gizi (AKG) tahun 2013 untuk populasi usia 10-18 tahun. Sebaliknya, asupan kolesterol dan vitamin A diketahui lebih besar daripada jumlah yang direkomendasikan.

Asupan karbohidrat yang adekuat penting bagi atlet karena dapat digunakan saat latihan intensitas tinggi, menjaga gula darah, dan menjadi simpanan glikogen otot. Asupan protein juga penting karena diperlukan untuk produksi enzim dan hormon dan memperbaiki jaringan yang rusak akibat latihan. Asupan lemak penting untuk produksi energi, melindungi organ, memberikan bantalan tubuh dan memfasilitasi asupan vitamin larut lemak dan asupan asam lemak esensial.

Asupan zat gizi mikro seperti vitamin dan mineral juga memberikan peran yang penting untuk kesehatan atlet. Vitamin dan mineral berperan pada pembentukan energi, sintesis hemoglobin, kesehatan tulang, fungsi imun, dan aktivitas antioksidan. Kebutuhan mikronutrien dapat dipenuhi dengan konsumsi asupan berenergi tinggi dan diet seimbang. Apabila kebutuhan vitamin dan mineral dapat dipenuhi dari diet, maka suplementasi vitamin dan mineral tidak diperlukan. ${ }^{17}$

Rekomendasi kebutuhan cairan untuk atlet adalah $150-250 \mathrm{ml}$ setiap 15 menit, dengan asumsi durasi latihan selama 4 jam (2.400-4.000 ml/ hari). Klasifikasi total asupan cairan bagi atlet dibagi menjadi kategori asupan kurang $(<4.900 \mathrm{ml})$, baik $(4.900-6.500 \mathrm{ml})$ dan lebih $(>6.500 \mathrm{ml}) .{ }^{18}$ Apabila dibandingkan dengan rekomendasi tersebut, ratarata pemenuhan asupan cairan pada atlet atletik PPLP DIY dan Aceh termasuk kurang (2.700-3.600 $\mathrm{mL}$ ), sementara rata-rata pemenuhan asupan cairan atlet atletik kelompok SKO Ragunan termasuk baik (5.800 mL).

Pemenuhan asupan cairan yang cukup berfungsi untuk menjaga atlet selalu dalam kondisi terhidrasi baik (euhidrasi), baik sebelum, saat, maupun setelah latihan. Secara umum, cairan yang disarankan untuk atlet adalah air mineral, minuman elektrolit, minuman yang mengandung karbohidrat, dan minuman yang mengandung protein. ${ }^{19}$ Karbohidrat dalam minuman membantu menyuplai zat energi dalam bentuk cairan sehingga lebih mudah diserap untuk dapat segera menggantikan glukosa darah yang hilang selama latihan serta membantu proses pemulihan. Minuman yang mengandung protein seperti susu dan minuman olahannya bermanfaat untuk memperbaiki jaringan otot saat proses pemulihan. Selain itu, asupan jus buah dan minuman yang mengandung vitamin $C$ juga baik bagi atlet sebagai antioksidan yang membantu meningkatkan imunitas tubuh. ${ }^{20}$

\section{Kesimpulan}

Atlet atletik laki-laki dalam kajian ini memiliki status gizi normal sedangkan status gizi gemuk masih ditemukan pada atlet perempuan. Somatotipe yang sesuai dengan standar atlet semi-profesional ditemukan pada atlet laki-laki. Persentase lemak diketahui berlebih dibandingkan nilai rekomendasi pada kedua jenis kelamin. Pemenuhan kebutuhan energi, zat gizi makro, zat gizi mikro, serta asupan cairan atlet secara keseluruhan masih tergolong 
kurang sehingga diperlukan peningkatan asupan makan. Pemberian diet serta jenis latihan yang tepat diperlukan agar pemenuhan energi dan zat gizi serta somatotipe yang sesuai dapat tercapai sehingga menunjang performa terbaik atlet.

\section{Ucapan terima kasih}

Penulis mengucapkan terima kasih kepada seluruh atlet yang berpartisipasi, pelatih, dan pengurus PPLP DIY, PPLP Aceh, dan SKO Ragunan, Jakarta Selatan yang telah memfasilitasi proses pengambilan data, serta Kementerian Pemuda dan Olahraga Republik Indonesia yang mendanai kajian ini.

\section{Daftar pustaka}

1. Flatt $A A$, Esco MR. Endurance performance relates to resting heart rate and its variability: A case study of a collegiate male cross-country athlete. J Aust Strength Condit. 2014;22:39-45.

2. Utami D. Peran fisiologi dalam meningkatkan prestasi olahraga Indonesia menuju SEA Games. J Olahraga Prestasi. 2015;11:52-63

3. Penggalih MHST, Juffrie $M$, Sudargo $T$, Sofro ZMS. Correlation between dietary intake with anthropometry profile on youth football athlete in Indonesia. Asian J Clin Nutr. 2017;9:916.

4. Yadav KR. A Study anthropometric measurement, body composition and somatotyping of high jump and shot put athletes. Int J Phys Educ. 2014;7(2):67-70.

5. Kementerian Kesehatan Republik Indonesia. Keputusan Menteri Kesehatan Republik Indonesia Nomor: 1995/MENKES/SK/XII/2010 tentang Standar Antropometri Penilaian Status Gizi Anak. Jakarta: Direktorat Jenderal Bina Gizi dan Kesehatan Ibu dan Anak, Kementerian Kesehatan Republik Indonesia; 2010.

6. Carter JEL. The Heath-Carter anthropometric somatotype. San Diego, CA, USA: San Diego State University; 2002.

7. Underhay $\mathrm{C}$, Ridder JH, Amusa L, Toriola A, Agbonjinmi A, Adeogun J. Physique characteristics of world-class African longdistance runners. AJPHERD. 2005;11(1):6-16.
8. Abraham B. Relationship of somatotypes components of selected psychological variables and fitness status of sprinters. Review of Research. 2012;1(10):1-4.

9. Duquet W, Carter JE Lindsay. In: Eston R, Reilly T. (Ed). Kinanthropometry and exercise physiology laboratory manual: Anthropometry. 3rd ed. New York: Routledge; 2009. Chapter 2.

10. Ackland TR, Lohman TG, Sundgot-Borgen J, Maughan RJ, Meyer NL, Stewart AD. Current status of body composition assessment in sport: Review and position. Sports Med. 2012;42(3):227-49.

11. Rogol AD, Clark AP, Roemmich JN. Growth and pubertal development in children and adolescents: effects of diet and physical activity. Am J Clin Nutr. 2000;72(2 Suppl):521S85 .

12. Burke L, Cox G. The complete guide to food for sport performance peak nutrition for your sport. 3rd ed. Crown Nest Australia: Allen \& Unwin; 2010. p. 303.

13. Dave P, Subhedar R, Mishra P, Sharma D. Body composition parameter changes among young male and female competitive swimmers and non-swimmers. Int J Med Sci Public Health. 2016; 2015;5(1).

14. William $\mathrm{MH}$. Nutrition for health, fitness and sport. 10th ed.. New York, USA: McGraw-Hill Education; 2013. p. 688.

15. Carassco L, Pradas F, Martinez A. Somatoype and body composition of young top-level table tennis players. Int J Table Tennis Sci. 2010;6:175-7.

16. Shepard RJ, Astrand P-O. La resistencia en el deporte. Barcelona: Paidotribo; 1998.

17. Cotugna N, Vickery CE, McBee S. Sports nutrition for young athletes. I Sch Nurs. 2005;21(6): 323-8.

18. Sawka MN, Louise MB, Eichner ER, Maughan RJ, Montain SJ, Stachenfeld NS. American college of sports medicine position stand: Exercise and fluid replacement. Med Sci Sports Exerc. 2007;39(2):377-90.

19. Wesley J. Sports hydration: '07: Endurance 
sports, rehydration, cerebral edema and death. New York: Northeastern Association of Forensic Scientists; 2006.

20. Greenwood M, Kalman DS, Antonio J, eds. Nutritional supplements in sports and exercise. New Jersey: Human Press; 2008. Chapter Nutritional supplements to enhance recovery.
21. Kementerian Kesehatan Republik Indonesia. Peraturan Menteri Kesehatan Republik Indonesia Nomor 75 Tahun 2013: Tabel angka kecukupan gizi (AKG) bagi bangsa Indonesia. Jakarta: Kementerian Kesehatan Republik Indonesia; 2013. 